\title{
Ensuring Effective and Efficient Teaching and Learning Religious Studies in Nigerian Schools Using Photographic Series
}

\author{
Sofowora Olaniyi Alaba
}

\begin{abstract}
The purpose of this study was to find out the extent to which the use of photographic series with sound in teaching religious studies could enhance the performance of students in selected junior secondary school in Remo Educational zone. It also investigated the extent to which talking photographic series could enhance the retention and the attitude of the students. Two hundred students in JSSIII were selected from five secondary schools through simple random sampling technique. They were also randomly divided into 2 groups, the experimental and control groups. The study adopted the pre-test, posttest group design. The instruments used were a series of photographs with sound prepared by the researcher and the students containing "churches and its relevance to the society", Religious studies Achievement Test (RSAT) and Attitude towards Religious Studies Questionnaire (ATRSQ). These instruments were validated using construct validity, difficulty and discriminating index. The reliability coefficient for the RSAT was found to be 0.75. The results showed that the use of photographic series in instruction significantly improved the performance of students in the subject. Secondly if effectively used, it can improve the retentive ability of students and finally, photographic series do not seen to have any statistical effect on the attitude of students towards the subject.
\end{abstract}

\section{Introduction}

In Nigeria today as more than ever before there is greater demand for highly creative and innovative teachers who can lead the students onto paths of meaningful learning. An effective and efficient teacher is also one of the factors that will contribute to effective instruction in 
education. The achievement of effective and efficient teaching and learning in schools has been one of the perennial problems in education. Other problems include the nature of the curriculum, controversial nature of the subjects and poor methods of instruction.

One of such subjects that is difficult to teach is religious studies. Religious studies before lay emphasis on factual examination oriented approach and religious dogmas. Today, it has become a matter of investigation and experimental rather than indoctrinations. Several factors have been attributed to the controversial nature of the subject. They include:

- The nature of the subject

- Confusion arising from the values of the theological idea

- Theological values that characterized the contemporary thought about religious (Cox 1966),

- The scope, meaning and concept of religious studies (Wester Hoff 1978).

According to WesterHoff (1978), though the name Religious Studies has been used most frequently, there is no complete or consistent agreement on what the word mean or what it refers to. Today, there is less concurrence than ever before.

In schools today, there are still different terminologies for the subject. Some prefer Religious Studies. In some cases they are used interchangeably. Scott (1980) says that no consensus exists today on the nature, scope and role of Religious Studies. The above named scholar believe that current search to identify revolves around different usage of key terms like Religious Education, Religious Knowledge Religious and Moral Instruction. Other problem is that since Religion deals with values, judgments and feelings, everyone in the society will agree with it. The implications of the above is that the controversial nature of the subject, lack of consistent linguistic discourse and the unstable pattern of conversation currently going on in the field have contributed to making the subject difficult and technical. 
Teague (1984) also speaks on the poor methods of communicating/teaching the subject. During the National Conference of the National Association of Bible Knowledge Teachers of Nigeria (NABKTN) held at Bauchi State Polytechnic in 1989, it was revealed that there had been a serious reduction in the enrolment of students in the subject at secondary schools level and tertiary institution of learning. A survey carried out at Obafemi Awolowo University, IleIfe (1995-2006) also revealed the same low enrolment as is shown in table 1. Other findings revealed that religious thinking among individual student is confusing and inarticulate. It was also found that simple lessons taught were not being retained for a long time by students (Sofowora 1994). Teague (1984) shows that the serious problem facing the teaching of the subject is lack of modern relevant instructional materials and textbooks.

The importance of modern technologies in Religious Studies cannot be under estimated. The application of relevant and modern technologies may help to solve some of the identified problems faced in the effective teaching of the subject. It is therefore an age long belief in Educational Technology that modern technologies are essential for effective and efficient teaching and learning. However, Sofowora (2002) shows that not all media materials that are available are technically suitable for use in teaching. He emphasized the need for training teachers in the art and craft of design selection production and use of appropriate needs. The required skills in the area mentioned above can only be acquired through Educational Technology. One of the major concerns of Educational Technology is the quest for effective instruction which is reflected in its definition. The United State Commission in Instructional Technology (1970) described Educational Technology as:

the systematic way of designing, carrying out and evaluating the total process of learning and teaching in terms of specific objectives based on research in human learning and communication, by employing a 
combination of human and non human resources to bring about effective instruction (p. 5).

Ogunmilade (1984) stated that Educational Technology can help to rectify the imbalance in the process of teaching and learning. It is with this recognition that the Federal Government established the defunct National Educational Technology Centre, Kaduna that has now metamorphosed into an arm of the National Open University Nigerian Abuja (NOUN).

According to Sofowora (2001) instructional media enhances comprehension, retention and recall. He is also of the opinion that when information is difficult to explain verbally and where specific procedure will need to be performed; the use of instructional media will not only illustrate the teacher's concept but add emphasis to the essential point, the use of instructional media will not only illustrate the teachers concept but add emphasis to the essential point.

Akanbi (2007) explained that children learn in 2 ways orally and visually. Many of them learn more rapidly where oral teaching is linked with visuals or concrete things they can see, touch or handle. Akanbi also further explain that a teacher cannot be certain that his/her verbal description will convey the correct meaning especially if the teacher finds it difficult to compare the concepts being described with those things the students already know. According to the above scholar, this can be corrected if relevant instructional media is used. The implication of all this is that Religious Studies cannot be effectively taught if teacher are not skilled in the art and craft of designing, development and production of education media.

\section{Statement of Problem}

The nature of religious studies, the placing of emphasis on factual examination and religious dogmas, poor method of teaching are some of the factors responsible for the poor performance and low enrolment of students in the subject. Other problems with the subjects include skeptical attitude of teachers, students and parents. The lack of 
relevant instructional media and textbooks with the rigidity of the tradition approach of teaching necessitated a change from the factual examination oriented approach to a more creative experiential approach. It must also be seen as investigation rather than indoctrination. This explains the need for a better approach to the teaching of Religious Studies. The problem this study was designed to examine was the extent to which photographic series could improve the performance of students in Religious studies. Apart from its influence on the cognitive achievement of the student, it examined the influence it has on the attitude of students toward the subject. Specifically, the study is intended to provide empirical answer to the following questions:

(a) does the use of photographic series improve the performance of students in Religious Studies?

(b) does the use of photographic Series help students to develop positive attitude towards Religious Studies?

(c) Is there any significant difference in the level of retention of students taught with photographic series and those taught without it?

\section{Research Objectives}

The following objectives were stated for this study:

(i) find out whether or not photographic series would bring about significant improvement in the performance of students in Religious Studies,

(ii) examine the extent to which photographic series would influence the attitude of student toward Religious Studies,

(iii) Investigate the extent to which the use of photographic series would improve the retention ability of students in Religious Studies

\section{Hypotheses of the Study}

The following hypotheses were stated for the study: 
$\left(\mathrm{Ho}_{1}\right)$ There will be no significant difference between the academic achievement of students taught Religious Studies with photographic series and those taught without it,

$\left(\mathrm{Ho}_{2}\right)$ There is no significant difference in the retention level of the students taught Religious Studies with photographic series and those taught without it.

\section{Theoretical Framework}

The theoretical framework is based on the theories of Perception (Murphy 1951 and Dale 1969) and Audio Visual theory. Dale (1969) opines that learning stems from perception and lack of initial correct perception inhibits learning. Sofowora (2001) quoting from the audio visual theory says:

We learn $33 \%$ of what we see $10 \%$ of what we hear $4 \%$ of what we teach and $1 \%$ of what we taste after learning we are able to retain $20 \%$ of what we hear and see, $70 \%$ of what we say and $90 \%$ of what we see, say and do.

Miller (1997) also identified four essentials of learning namely: derive, cue, response and reward. According to this school of thought: drive (motivation) typifies that the learner want something, cue (stimulus) learner must notice something, response (participation) the learner must be engaged, reward(reinforcement), learner must achieve or get what he/she desires.

The implication of the above is that for effective learning to take place, learners must be motivated, provided with cues and be allowed to participate actively in the instructional process. Also the ability of the learners to assign meaning to pictures includes the ability to recognize, integrate and interpret correctly the several items in the pictures.

All the above were employed in the design and production of the photographic series. In order to produce the photographic series 
used, the researcher developed production script containing information and types of shot. The students were divided into a group of ten thus making 20 participants in each group. They were given orientation, training on what is expected of them. The students were given digital cameras and were guided to the field to take the required photographs with the help of research assistance from the Department of Educational Technology. The exercises lasted for two weeks. After the film exposure, all the students' productions were collected and processed through the computer.

The different photographic shots were printed on 8 x 12 cards. They were sorted out; those that met the production qualities were selected and displayed in an album for student use. The rest were displayed on a white interactive board for exhibition. Audio containing short information about the content of the photographic series were synchronized into the production. The contents of the structured photographic series were; the church, Christian homes, responsibilities of Christian in the society and Christian and public lives. These topics were obtained from the school curriculum.

\section{Methodology}

This research adopted the pre-test, post-test control group design by Campbell and Stanley (1972). The sample for the study consisted of all the junior secondary school students in Remo Education Zone. 200 students were selected from 5 secondary schools constituting 40 students from each school. One hundred students were assigned to each of the excremental and control group. Three major instruments used in the study were:

(i) A (50) series of structured and talking photographic series displayed (a) in an album. (b) Another sets displayed on white interactive board.

(ii) Attitude towards Religious Studies Questionnaire (ATRSQ).

The RSAT contained twenty five items with multiple choice responses. This was used to measure student performance in both 
pre-test, post-test and retention test. The research instrument was based on the syllabus for the junior secondary school students in Nigeria's. The students had 7 lessons that were spread over eight weeks. The topic treated was "Christian's church today".

A questionnaire schedule was also used to examine the attitude of the students towards Religious studies. It was rated on a five point Likert scale (i.e. $\mathrm{SA}=$ Strongly Agreed, $\mathrm{A}=$ Agreed, UD= Undecided, $\mathrm{D}=$ Disagreed, $\mathrm{SD}=$ Strongly Disagreed. In order to validate the instruments, the level of difficulty and the discriminating power of each item of the test were determined. Using the Nisbert and Entwistle (1970) discrimination index of 30\% the forty test items were reduced to 25 items. For the attitude test, the construct and criterion validity was used. The reliability coefficient for the achievement test was determined using Kudder Richardson formulae. A coefficient of 0.75 was contained.

\section{Results}

The result of the analysis of the data collected in respect of hypothesis is presented in Table 2 .

The result of the analysis at the pre-test showed that there was no significant difference in the performance of the students before exposing there to the talking photographic series. The mean score for the experimental group was 36.75 while that of the control group was 35.90. When this was subjected to a t-test analysis, it gave a result of $\mathrm{t}=0.53, \mathrm{df}=198 \mathrm{P}>0.005$. After exposure to treatments, the post-test mean score for the experimental was 61.90 and control mean store 54.3. When the mean scores were subjected to t-test analysis, the obtained $\mathrm{t}$-value of 4.02 was found to be significant ( $\mathrm{t}=$ 4.02; $\mathrm{df}=198, \mathrm{P}<0.05)$.

It implied that students in the experimental group performed significantly better than those in the control group at the end of the treatment. Thus the first hypothesis was rejected. (See table 3) 
The result obtained with respect to hypothesis 2 showed that at pretest t-value of 0.99 at 0.05 significant level was obtained. At post test, the experimental group had a mean score of 40.46 while control group had 38.45. When subjected to t-test, the result obtained was $(\mathrm{t}=1.86, \mathrm{df}=198 \mathrm{P}>0.05)$. It implied that 6the package used statistically had no significant effect on the attitude of the students. This may probably be attributed to shoot duration of the experiment, only seven lessons were used. It might be too few to have a great and lasting effect on the attitude of the students toward the subject.

The data collected with respect to Hypothesis 4 revealed that the students in the experimental group had a mean score of 69.47 while those in the control group had a mean score of 54.40. When this was subjected to a t-test, it showed that there was a significant difference in the level of retention of the students taught Religious Studies with the talking photographic series. $(\mathrm{t}=8.32, \mathrm{df}=198 \mathrm{P}<0.05)$. Hence the null hypothesis III was rejected.

The fact that those in the experimental group performed significantly better than the students in the control group is suggestive of the idea that some of the factors causing loss of retention might have been reduced by the use of photographic series. Other unscientific generalization might include proactive inhibition and emotional instability. The talking photographic series might have motivated the students, reinforced the teaching for easy assimilation and retention. It therefore implied that photographic series could effectively improve significantly learners' retention level.

\section{Conclusion}

The use of photographic series as shown in this study had enhanced effective and efficient teaching/learning of Religious Studies thereby improving the performance of students. It seems to have some influence on the attitude of the students taught Religious 
Studies although the changes were not statistically significant but it has educational significance.

It also improved the level of retention of the students in Religious studies. Conclusively, photographic activities if encouraged and used constantly might enhanced effective teaching and learning in schools.

\section{Recommendations}

- The use of photography in teaching especially Religious Studies in the schools should be encouraged;

- Schools should be encouraged to establish a photographic club or society;

- Seminars, workshops and in-service training should be organized for teachers to enable them acquire knowledge and skills about design selection, production and use of modern technologies and photography in schools.

\section{References}

Akanbi, D. K. (2007). "Teaching and Learning Environment for Space Education; A systems Approach." A Paper Presented during the Space Science Workshop held at Obafemi Awolowo University, Ile-Ife.

Campbell, D. T. and Stanley, H. C. (1972): Experimental and Quasi Design for Research. Chicago: Rand Mac Nally and Co.

Cox, E: (1969). Changing Aim in Religious Education. New York: Routedge and Kegan.

Dale, E. A. (1960) Audio-Visual Methods in Teaching (3rd ed). New York: Holt Rhine Hart and Wintson.

Miller, N. .E. (1957). Communication and the Crisis in Education. Washington D. C.: National Education Association (pp 120133).

Murphy G. (1951). "Perceptual Development, some Tentative Hypotheses." Psychological Review (pp. 331-341). 
Ogunmilade, C. A. (1985). Media in Education, Ile-Ife, Obafemi Awolowo University of Ile-Ife Press.

Scatt, K. (1980). "Communication Competence and Religious Education." Lumen Villa 35 pp. 75-96.

Sobak, E. (1989): "A Survey of the Principle and Methods of Teaching in Religious Studies." Journal of the National Association of Bible Teachers of Nigeria XV (pp p-150.

Sofowora, O. A. (1994). "Towards Effective and Efficient Management of Instructional Materials in Schools." Journal of the Educational Mediated Technology.

Teague, F. A, (1989). "An Evaluation Instrument of Audio Visual Materials in religious Education" 773 pp. 612-616. Unpublished M. A. Thesis Submitted to the Faculty of Education. Department of Educational Technology, Obafemi Awolowo University, Ile-Ife.

Westerhoff J. (1978). "Who are We? The Quest for Religious Education." Religious Education 673 pp. 590-596. 
Table 1: Student Enrolment (1995-2006)

\begin{tabular}{|c|c|c|c|c|c|c|}
\hline \multirow{2}{*}{$\begin{array}{l}\text { Academic year } \\
\text { Undergraduate }\end{array}$} & \multirow{2}{*}{$\begin{array}{l}\text { Title of } \\
\text { Programme }\end{array}$} & \multicolumn{4}{|l|}{ Enrolment } & \multirow{2}{*}{$\begin{array}{l} \\
500 \\
\text { Level }\end{array}$} \\
\hline & & 100 Level & $\begin{array}{l}200 \\
\text { Level }\end{array}$ & $\begin{array}{l}300 \\
\text { Level }\end{array}$ & $\begin{array}{l}400 \\
\text { Level }\end{array}$ & \\
\hline 1995/1996 session & B.A. Education & 0 & 4 & 6 & 5 & \\
\hline 1996/1997 session & B.A. Education & - & 4 & 4 & 7 & \\
\hline 1997/1998 session & B.A. Education & 5 & 3 & 8 & 4 & \\
\hline 1998/1999 session & B.A. Education & 0 & 5 & 3 & 8 & \\
\hline 1999/2000 session & B.A. Education & 1 & 3 & 5 & 4 & \\
\hline $2000 / 2001$ session & - & - & - & - & - & \\
\hline $2001 / 2002$ session & B.A Education & 1 & 1 & 3 & 5 & \\
\hline $2003 / 2004$ session & B.A Education & - & 0 & 11 & 8 & \\
\hline 2005/2006 session & B.A Education & 3 & 3 & 1 & 10 & \\
\hline 200062007 session & B.A. Education & 3 & 3 & 1 & 7 & \\
\hline
\end{tabular}

Source: Admission Office, Obafemi Awolowo University, Ile-Ife

Table 2: Comparison of the Performance of the Students in the Experimental and Control Groups

\begin{tabular}{|l|l|l|l|l|l|l|l|}
\hline Test & \multicolumn{1}{|c|}{ Group } & N & $\frac{\text { SD }}{X}$ & $\mathbf{~ d f}$ & P=0.05 \\
\hline $\begin{array}{l}\text { Pre- } \\
\text { test }\end{array}$ & $\begin{array}{l}\text { Experimental } \\
\text { Control }\end{array}$ & 100 & 36.75 & 10.77 & & & \\
\hline $\begin{array}{l}\text { Post- } \\
\text { Test }\end{array}$ & $\begin{array}{l}\text { Experimental } \\
\text { Control }\end{array}$ & 100 & 35.90 & 11.97 & 198 & 0.53 & $>0.05$ \\
\hline
\end{tabular}

*Significance $\mathrm{P}<0.05$ 
Table 3: Comparison of the Attitude of the Students in the Experimental and Control Groups.

\begin{tabular}{|l|l|l|l|l|l|l|l|}
\hline Test & \multicolumn{1}{|c|}{ Group } & N & SD & df & t & P=0.05 \\
\hline $\begin{array}{l}\text { Pre- } \\
\text { test }\end{array}$ & $\begin{array}{l}\text { Experimental } \\
\text { Control }\end{array}$ & 100 & 38.65 & 8.19 & & 0.99 & \\
\hline $\begin{array}{l}\text { Post- } \\
\text { Test }\end{array}$ & Experimental & 100 & 37.45 & 8.89 & 198 & & $>0.05$ \\
\hline
\end{tabular}

*Significance $\mathrm{P}>0.05$

Table 4: Comparisons of Retention Test Scores of the students in both Experimental and control Groups

\begin{tabular}{|c|c|c|c|c|c|c|c|}
\hline Test & Group & $\mathbf{N}$ & $\bar{X}$ & SD & df & t & $\mathbf{P}$ \\
\hline Retention & Experimental & 100 & 69.47 & 12.38 & 198 & 8.32 & $\begin{array}{l}<0.0 \\
5\end{array}$ \\
\hline Test & Control & 100 & 54.40 & 13.22 & & & \\
\hline
\end{tabular}

*Significance $\mathrm{P}<0.05$ 